\title{
Vazodilatační léčba aneb 20 let klinických studií srdečního selhání*
}

\author{
Jiří Vítovec \\ I. interní-kardioangiologická klinika, Fakultni nemocnice u sv. Anny a Lékařská fakulta Masarykovy univerzity, \\ Brno, Česká republika
}

Motto: „Nikdy nic nikdo nemá míti za definitivní neb nikdy nikdo neví co se může státi..."

Voskovec + Werich, píseñ ze hry Golem, 1931

V letošním roce vyšly v Cor Vasa dvě úvahy nad klinickými studiemi. Prof. Widimský sen. podal přehled o kladech a úskalích medicíny založené na důkazech (EBM) a kromě jiného si postěžoval, že se lékaři při léčbě málo řídí závěry, které vyplývají z EBM.(1) Prof. Špinar v májovém úvodníku vtipně rozebral téma „co nám říkaji klinické studie s negativním či neutrálním výsledkem“, kde částečně zpochybňuje užitî tzv. náhradních („surrogate“) cílů (například hemodynamických) místo jednoznačného a „tvrdého“ cíle - mortality. ${ }^{(2)}$

Oba tyto velmi podnětné články mě inspirovaly k zamyšlení nad první multicentrickou a mortalitní studií u nemocných s chronickým srdečním selháním, která byla publikována právě před 20 lety,(3) ale bohužel na žádném letošním americkém, českém, evropském a světovém kardiologickém sjezdu či kongresech o srdečnim selhání toto významné výročí nebylo vzpomenuto.

Autorský kolektiv pod vedením prof. Jay N. Cohna publikoval v letech 1986, 1991 a 2004 mortalitní studie, které testovaly stejnou vazodilatační kombinaci léků: hydralazin s izosorbiddinitrátem (HZ + ISDN). Všechny práce byly publikovány $\mathrm{v}$ New England Journal of Medicine pod akronymy Vasodilator nebo African-American Heart Failure Trial (V-HEFT I, V-HEFT II a A-HEFT) a nebyly nikdy v našem písemnictví podrobně rozebírány; přitom ale podávají velmi cenné informace o změně pohledu na vazodilatační léčbu srdečního selhání.

Studie V-HEFT I byla uveřejněna v roce 1986, jako dvojitě slepá multicentrická studie u 642 mužů se stabilizovaným chronickým srdečním selháním - funkčně NYHA II a III, s poruchou srdeční funkce (kardiothorakální index /CRT/ > 0,55 na rentgenu nebo diastolický rozměr levé komory $>2,7 \mathrm{~cm} / \mathrm{m}^{2}$ na echokardiografii nebo ejekční frakce < $45 \%$ a $\mathrm{k}$ tomu spirometricky určená spotřeba max. $\left.\mathrm{O}_{2}<25 \mathrm{ml} / \mathrm{kg} / \mathrm{min}\right)$. Základní-

Adresa: prof. MUDr. Jiř́i Vítovec, CSc., FESC, I. interní-kardioangiologická klinika, FN u sv. Anny a LF MU, Pekařská 53, 65691 Brno, Česká republika, e-mail: jiri.vitovec@fnusa.cz mi léky byly diuretika a srdeční glykosidy. Byly testovány dva léčebné vazodilatační režimy. Alfa-1 blokátor adrenergních receptorů - prazosin do cílové dávky $4 \times 5$ mg u 183 nemocných, kombinace přimých vazodilatačních léků - hydralazinu (HZ) (až $4 \times 75 \mathrm{mg} / \mathrm{den}$ ) a izosorbiddinitrátu (ISDN) (až $4 \times 40 \mathrm{mg} /$ den) u 186 pacientů, do placebové větvě bylo zařazeno 273 nemocných. Prưměrná doba sledování byla 2,3 roky (od 6 měsíců po 5,7 roků) a primárním cílem byla celková úmrtnost. $\mathrm{V}$ prvním roce došlo ke snížení rizika úmrtnosti u nemocných léčených kombinací $\mathrm{HZ}+$ ISDN o $38 \%$, ve druhém o $25 \%$ a ve třetím o $23 \%$. Mortalita po prazosinu byla obdobná jako při placebu. Na základě těchto výsledků bylo možno konstatovat, že vazodilatační léčba kombinací $\mathrm{HZ}$ + ISDN je účinná v léčbě chronického srdečního selhání a zlepšuje nejen kvalitu života, ale hlavně může významně snížit úmrtnost; naopak prazosin se $\mathrm{v}$ dlouhodobém podávánî ukázal jako neúčinný. (3)

Jelikož již v té době byly důkazy o prospěšnosti inhibitorů angiotenzin konvertujícího enzymu, autoři naplánovali další mortalitní srovnávací studii bez placeba - V-HEFT II. Do této studie bylo zařazeno celkem 804 mužů (71 \% bělochů a 27 \% Afroameričanů) se stejnou poruchou srdeční funkce jako ve studii V-HEFT I, kteří byli randomizováni na léčbu inhibitorem angiotenzin konvertujícího enzymu - enalaprilem (do dávky $20 \mathrm{mg}$ ) nebo kombinací hydralazinu s ISDN (300 mg + 160 mg). Primárním cílem byla opět mortalita, sekundárním cílem hemodynamické změny (ejekční frakce a spotřeba kyslíku na vrcholu zátěže). Doba sledování byla od 6 měsíců do 5,7 let (průměr 2,5 roku). Snížení rizika úmrtnosti po enalaprilu bylo $\mathrm{v}$ prvním roce o $33,6 \%$, ve druhém o $28,2 \%$ $(p=0,016)$, na konci studie o $11,1 \%(p=0,08)$. Enalapril snížil významně výskyt náhlé smrti a pokud jde o úmrtí na terminální selhání nebylo významného rozdílu mezi oběma léčenými skupinami. Ve studii se ukázal rozpor mezi hemodynamickým účinkem léčby a úmrtností, protože ejekční frakce i vrcholová spotřeba kyslíku při zátěži se naopak významně zlepšily po kombinaci HZ + ISDN. Nežádoucí účinky - bolesti hlavy - byly častější u kombinace HZ + ISDN a u $21 \%$ nemocných vedly $\mathrm{k}$ přerušení léčby. Po enalaprilu bylo méně nežádoucích účinků, pouze $6 \%$ nemocných bylo vyřazeno pro symptomatickou hypotenzi 
nebo kašel. Závěrem autoři konstatují, že jak enalapril, tak kombinace hydralazinu a nitrátu mají nezávislý přiznivý účinek a měly by být podávány společně. ${ }^{(4)}$

Po retrospektivních analýzách předchozích studií, kde u Afroameričanů byla kombinace $\mathrm{HZ}+$ ISDN účinnější, (5) bylo provedeno srovnání kombinace $\mathrm{HZ}+$ ISDN ve srovnání s placebem, ale pouze u této skupiny obyvatel - studie A-HEFT. Bylo do ní zařazeno 1050 nemocných ve funkční klasifikaci NYHA III a IV. Porucha srdeční funkce byla obdobná jako $\mathrm{v}$ předchozích studiích, nemocní museli být léčeni standardně, včetně neurohumorální blokády, tj. inhibitory ACE či sartany (76\%), betablokátory (74\%), digoxinem (59\%), diuretiky (90\%) a případně spironolaktonem (38\%). Dávkování aktivní léčby ve srovnání s předchozími studiemi bylo sníženo; $\mathrm{HZ}$ $(3 \times 75 \mathrm{mg})$ a ISDN $(3 \times 40 \mathrm{mg})$. Studie byla předčasně ukončena pro významný pokles úmrtnosti při kombinaci $\mathrm{HZ}+$ ISDN o $43 \%(p=0,02)$. První hospitalizace pro srdeční selhání při placebu byla nutná ve $24,4 \%$ ve srovnání s $16,4 \%$ při kombinační léčbě a toto snížení bylo statisticky významné $(p=0,001)$. Výskyt bolesti hlavy byl vysoký - u 47,5 \% nemocných a závratě u 29,3 \% osob. Autoři uzavírají, že přidání fixní kombinace $\mathrm{HZ}$ a ISDN Afroameričanům k standardní léčbě zlepší jejich přežití. Závěr byl ale opatrně formulován a bylo zdưrazněno, že budoucí strategie by měla identifikovat nemocné spíše na základě genotypu a fenotypu než provádět výběr léčby podle rasových či etnických charakteristik. ${ }^{(6)}$

Patofyziologické a farmakologické podklady pro použití kombinace hydralazinu a ISDN u srdečního selhání byly původně vysvětlovány jejich vazodilatačními vlastnostmi (HZ na tepenný systém a ISDN na žilní cévní systém) s následným snížením dotížení a předtížení. ${ }^{(7)}$ Později se prokázalo, že tento příznivý hemodynamický účinek je dán uvolněním oxidu dusného (NO) s následným ovlivněním remodelace myokardu i cévní stěny. Nitráty slouží jako donor NO a hydralazin působí proti oxidativní degradaci NO. ${ }^{(8)}$

První studie prokázala přiznivý vliv na přežití při léčbě kombinací $\mathrm{HZ}$ a ISDN ve srovnání s placebem i prazosinem. Nejvyšší úmrtnost byla $\mathrm{v}$ placebové větvi u ischemické choroby srdeční (ICHS), stejná mortalita pro $\mathrm{HZ}+$ ISDN u ICHS a po placebu u neischemického selhání. Nejnižší úmrtnost byla při užití $\mathrm{HZ}+$ ISDN u selhání neischemické etiologie. Do studie byl zařazen poměrně malý počet nemocných, přes 200 v každé sledované skupině a statistický rozdíl byl v úmrtnosti po dvou letech, $p=0,028$, což sami autoři pokládali za hraniční. Studie ukázala rozdíl v přeživání nemocných se srdečním selháním ischemické a neischemické etiologie a již tehdy upozornila na neúčinnost prazosinu v léčbě chronického srdečního selhání. (3) Prof. Widimský upozornil na nedodržování doporučení v léčbě kardiovaskulárních onemocnění, (1) tuto kombinaci při netoleranci inhibitorů ACE či sartanů - jak je i v nových doporučeních pro léčbu srdečního selhání uváděna (doporučení I, evidence B) ${ }^{(9)}$ - zcela jistě podával minimální počet našich lékařů. Je to $z$ dưvodu obavy $z$ nežádoucích účinků, také pro nárůst polypragmazie (dalších 8 tablet $-4 \times 75 \mathrm{mg}$ $\mathrm{HZ}$ a $4 \times 40 \mathrm{mg}$ ISDN). Dnes mají lékaři situaci vyřešenu, hydralazin není na našem trhu $\mathrm{k}$ dispo- zici, takže mohou přidat pouze nitráty ke standardní léčbě.

Druhá studie V-HEFT II přinesla další zajímavé informace. Byl zde ukázán jasný rozpor mezi mortalitou a náhradním cílem - hemodynamikou. Zatímco mortalita byla nižší po enalaprilu, hemodynamika se významně zlepšila po kombinaci HZ + ISDN. Rozdílný byl vliv na výskyt náhlé smrti - nižší po enalaprilu, ale úmrtí na progredující srdeční selhání bylo u obou léčebných režimů stejné, obdobně jako úmrtí na ischemickou přičinu srdečního selhání. Na tento rozpor v klinických studiích právě poukázal prof. Špinar, ${ }^{(2)}$ mortalita a náhradní cíle se ve svém výsledku liší. Zajímavý je závěr autorů, když doporučují oba léčebné režimy kombinovat, místo aby doporučili jen použití ACE-inhibice. ${ }^{(4)}$

Třetí studie A-HEFT vycházela $z$ přiznivějšího působení kombinace $\mathrm{HZ}+$ ISDN u afroamerické populace $\mathrm{v}$ obou předchozích studiích a dále $\mathrm{z}$ poznat$\mathrm{ku}$ odlišných genových polymorfismů u lidských ras. ${ }^{(5,10)} Z$ tohoto důvodu byli do této studie zařazeni pouze Afroameričané. Protože autoři pokládali celkovou úmrtnost za přiliš hrubý ukazatel, zvolili zajímavý kompozitní primární cíl - skórovací systém (celkové úmrtí: -3; dožití konce studie: 0; první hospitalizace pro CHSS: -1; žádná hospitalizace: 0; změny kvality života: od +2 do -2 . Celkové možné skóre bylo od -6 do +2$)$. Tento kompozitní cíl byl na kombinaci $\mathrm{HZ}+\mathrm{ISDN}-0,1 \pm 1,9$ a na placebu $-0,5 \pm 2,0$ $\mathrm{s}$ významným statistickým rozdílem $(p=0,01)$. Na druhé straně pokles samotné úmrtnosti byl tak dramatický, že autoři studii předčasně ukončili a do léčby srdečního selhání Afroameričanů doporučili tabletu s názvem BiDil (HZ 37,5 mg + ISDN 20 mg). Tento poznatek přinesl $v$ USA řadu společenských, rasových i odborných otázek o výběru léčby podle rasy. ${ }^{(11)}$

Jaké poselství si můžeme $z$ těchto studií odnést? Za první potvrzení, že vazoaktivní léčba srdečního selhání je natolik účinná, že snížila úmrtnost a za druhé, že zlepšení hemodynamiky nemusí snížit úmrtnost a dále, že ovlivnění systému RAS pomocí inhibice ACE nemusí být jednoznačně výhodnější než kombinovaná vazodilatační léčba. Autoři proto doporučovali $\mathrm{v}$ roce 1991 oba tyto režimy kombinovat. Poslední studie upozornila nejen na rasové rozdíly v léčbě kardiovaskulárních onemocnění, ale také na vhodnost použití kompozitních primárních cílů, ${ }^{(12)}$ které zohlední nejen úmrtnost, ale také symptomatickou úlevu, nežádoucí účinky léčby a některé jiné ukazatele zpomalení progrese onemocnění, protože kvalita života není o nic méně významnější cíl léčby nemocných než statisticky vyjádřená nižší mortalita. ${ }^{(13)}$ Závěry klinických studiích ohledně stejné léčby se mohou dialekticky měnit. Ve studii V-HEFT I přímá vazodilatační léčba snižuje mortalitu a proto je doporučena do léčby srdečního selhání. Ve studii V-HEFT II - přímá vazodilatační léčba má mortalitu vyšší než inhibice ACE - přímá vazodilatační léčba je doporučena pouze při intoleranci inhibitorů ACE. Podle poslední studie A-HEFT u vybrané skupiny nemocných je úmrtnost po přimé vazodilataci nejnižší a proto je opět doporučována do kombinace u této skupiny pacientů. Jak uvádí motto od $\mathrm{V}+\mathrm{W}$, a co se ukázalo ve výše rozebraných studiích, platí v medicíně na $100 \%$. 


\section{LITERATURA}

1. Widimský J. Klady a úskalí „evidence based“ medicíny. Cor Vasa 2006;48:24-31.

2. Špinar J. Co nám říkají klinické studie $s$ negativním a neutrálním závěrem? Cor Vasa 2006;48:168-71.

3. Cohn JN, Archibald DG, Ziesche S, et al. Effect of vasodilator therapy on mortality in chronic congestive heart failure. Results of a Veterans Administration Cooperative Study (V-HEFT I). New Engl J Med 1986;314: 1547-52.

4. Cohn JN, Johnson G, Ziesche S, et al. A comparison of enalapril with hydralazine. Isosorbide dinitrate in the treatment of chronic congestive heart failure (V-HEFT II). New Engl J Med 1991;325:303-10.

5. Carson P, Ziesche S, Johnson G, Cohn JN. VasodilatorHeart Failure Trial Study Workgroup. Racial differences in response to therapy for heart failure: analysis of the Vasodilator-Heart Failure Trial. Card Fail 1999;5: 178-87.

6. Taylor AL, Ziesche S, Yancy C, et al. Combination of Isosorbide Dinitrate and Hydralazine in Blacks with
Heart Failure (A-HEFT). New Engl J Med 2004;351: 2049-57.

7. Massie B, Chatterjee K, Werner J, et al. Hemodynamic advantage for combined administration of hydralazin orally and nitrates nonparenterally in the vasodilator therapy of chronic heart failure. Am J Cardiol 1977;40: 794-801.

8. Ignarro LJ, Napoli C, Loscalzo J. Nitric oxide donors and cardiovascular agents modulating the bioactivity of nitric oxide: an overview. Circ Res 2002;90:21-8.

9. Swedberg K, Cleland J, Dargie H, et al. Guidelines for the diagnosis and treatment of chronic heart failure: executive summary (update 2005). Eur Heart J 2005;26:1115-40.

10. Cooper RS, Kaufman JS, Ward R. Race and genomics. New Engl J Med 2003;348:1166-70.

11. Haga SB, Ginsburg GS. Prescribing BiDil: Is It Black and White? J Am Coll Cardiol 2006;48:12-4.

12. Cohn JN. Efficacy and Safety in Clinical Trials in Cardiovascular Disease. J Am Coll Cardiol 2006;48:430-3.

13. Vítovec J. Hemodynamika vazodilatační léčby srdečního selhání. Kandidátská disertační práce. Brno: UJEP, 1988: 118 . 